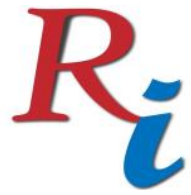

Asia Proceedings of Social Sciences

(APSS)

www.readersinsight.net/APSS

\title{
THE CONCEPT OF THE LAND REFORM IN CUSTOMARY LAW OF THE JAVANESE COMMUNITY
}

\section{Widhiana H. Puri}

Phd Student at Law Fakulty of Gadjah Mada

University and Lecture in National Land Academy

Indonesia.

*Corrosponding author's Email: widhianapuri@yahoo.com

Peer-review under responsibility of $3^{\text {rd }}$ Asia International Multidisciplanry Conference 2019 editorial board

(http://www.utm.my/asia/our-team/)

(c) 2019 Published by Readers Insight Publisher,

lat 306 Savoy Residencia, Block 3 F11/1,44000 Islamabad. Pakistan,

info@ readersinsight.net

This is an open access article under the CC BY-NC-ND license (http://creativecommons.org/licenses/by-nc-nd/4.0/). 


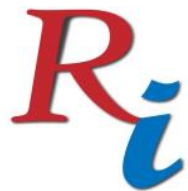

\section{Asia Proceedings of Social Sciences \\ (APSS) \\ www.readersinsight.net/APSS}

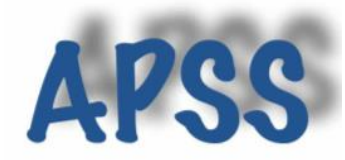

\section{Rese a r ch H igh I ight s}

Land reform is a state effort to overcome the imbalance of land tenure in the community (Wiradi, 2000 \# 1). Customary law in the Javanese community recognizes the existence of a mechanism of welfare distribution through the ownership and joint use of land in community togetherness bonds based on territorial factors as well as the concept of land reform. The existence of customary land as pekulen land is land owned by the village whose use rights can be requested by the villagers with a rotating utilization mechanism among the villagers in need (Luthfi, 2010 \# 2).

The study found that indigenous peoples in Java had a welfare distribution mechanism that was the essence of land reform or agrarian reform through a mechanism of land communalization and distribution of its use carried out on a shared land / communal land of the village in rotation.

\section{Research Objectives}

This research was conducted in order to understand the phenomena of the implementation of law that developed in the community. The existence of community law or so-called non state law, informal law, or customary law in Indonesia is very numerous. The reality of this law is that the majority is still far from the attention and order of a positive and formal state legal arrangement. The community regulation model is an effort to meet the needs of its legal ideals in the midst of limited state positive law arrangements that tend to be more static and less responsive (Puri, 2017 \# 16). The community regulation mechanism is a manifestation of unity in the village community where the distribution of land use is carried out among community members who have a concept in line with the national agrarian policy of the country called land reform. The regulatory model initiated from the local level becomes the learning material for how the land regulation mechanism is not always top down, but can be bottom up based on customary law that is proven effective and in accordance with the characteristics of the local community.

\section{Methodology}

This research was carried out through an empirical legal research model with research locations in villages in Pituruh Subdistrict, Purworejo Regency, Central Java Province. This research is a kind of analytical descriptive research that is directed to get an idea of how the implementation of Javanese traditions in land management has a concept similar to land reform or agrarian reform. In order to analyze existing traditions, a socio-legal approach is carried out, namely a study of the law using the approach of law and social sciences in order to analyze it (Irianto, 2012 \# 17). The legal approach referred to is not only to see aspects of norms that are built on the provisions of customary law alone but by looking at their relevance to the regulation of the positive law of the country as the territory of the enactment of the community regulation. This is to see the common thread and the interrelationship between the two and avoid the release of the phenomenon of legal pluralism that is within the scope of national law. So that the legal norms of the community can be assessed as the model of regulation that can be applied in other regions.

\section{Results}

Javanese people in Indonesia have a land regulation mechanism that has a concept similar to that of land reform or agrarian reform by the state. The customary law of the Javanese community has a common bond based on territorial factors or similarity in the area of residence 


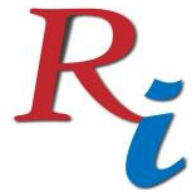

\section{Asia Proceedings of Social Sciences (APSS) \\ www.readersinsight.net/APSS}

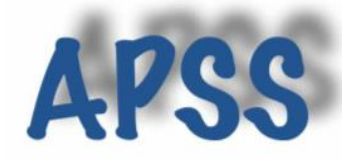

(Taneko, 2002 \# 11). Customary law communities with their customary rights can own and control land both in the concept of individual property rights and communal / communal property rights. The concept of shared property / communal rights illustrates the existence of ownership rights by all members of the community embodied in village control (Susanto, 1983 \# 18). One form of joint ownership is the right of possession which can be controlled by community members with the permission of the village government to be used for the benefit of themselves and their families with a rotating mechanism. At present, land is experiencing strengthening and individualization, but the character of togetherness and social function of land is maintained through the distribution of utilization rights of speculative land which has the status of individual property rights, in village settings.

\section{Findings}

Land reform or agrarian reform is a land policy that aims to overcome the imbalance of land tenure through the distribution of land to people in need. Land reform or agrarian reform can be extended not only to the concept of distribution of land ownership but also to the control and use of land. The limitations of the number of land parcels and the need for land can be overcome through a model of tenure and shared use of land based on the concept of joint property / communal rights over land.

\section{References}

Wiradi, G. (2000). Reforma Agraria, Perjalanan Yang Belum Berakhir (N. Fauzi Ed. 1 ed. Vol. -). Yogyakarta: Insist Press, KPA \& Pustaka Pelajar.

Luthfi, M. S. d. A. N. (2010). Land Reform Lokal Ala Ngandagan: Inovasi Sistem Tenurial Adat di Sebuah Desa Jawa, 1947-1965 (O. Sitorus Ed. 1 ed.). Yogyakarta: STPN Press dan Sajogyo Institute.

Puri, W. H. (2017). Pluralisme Hukum sebagai Strategi Pembangunan Hukum Progresif di Bidang Agraria di Indonesia. bhumi, 3 (Agraria dan Pertanahan), 67-81.

Irianto, S. (2012). Memperkenalkan Studi Sosiolegal dan Implikasi Metodologisnya In S. I. Adriaan W. Bedner, Jan Michiel Otto, dan Theresia Dyah W (Ed.), Kajian Sosio-Legal (Vol. 1, pp. 246). Denpasar: Pustaka Larasan.

Taneko, S. S. d. S. B. (2002). Hukum Adat Indonesia (5 ed. Vol. 5). Jakarta: RajaGrafindo Persada.

Susanto, R. (1983). Hukum Pertanahan Agraria (Vol. 2). Jakarta: Pradnya Paramita. 